\title{
Communication
}

[Comunicação]

\section{Experimental infestation with the immatures of Amblyomma dissimile Koch, 1844 (Acari: Ixodidae) on Tropidurus torquatus (Lacertilia: Iguanidae) and Oryctolagus cuniculus}

\author{
[Infestação experimental com as fases imaturas de Amblyomma dissimile Koch, 1844 (Acari: Ixodidae) em \\ Tropidurus torquatus (Lacertilia: Iguanidae) e Oryctolagus cuniculus] \\ L.H.T. Freitas ${ }^{1}$, J.L.H. Faccini ${ }^{1}$, E. Daemon ${ }^{2}$, M.C.A. Prata ${ }^{3}$, D.M. Barros-Battesti ${ }^{4}$ \\ ${ }^{1}$ Departamento de Parasitologia Animal \\ Instituto de Veterinária, Universidade Federal Rural do Rio de Janeiro \\ BR $465, \mathrm{~km} 7$ \\ 23.890-000 - Seropédica, RJ \\ ${ }^{2}$ Instituto de Ciências Biológicas - UFJF - Juiz de Fora, MG \\ ${ }^{3}$ Embrapa - Gado de Leite - Juiz de Fora, MG \\ ${ }^{4}$ Laboratório de Parasitologia - Instituto Butantan - São Paulo, SP
}

The geographic distribution of Amblyomma dissimile Koch includes Florida, Mexico, Antilles, Colombia, Venezuela, Argentina, and several states of Brazil (Fairchild et al., 1966; Guimarães et al., 2001).

The natural hosts for this species of tick are reptiles and amphibians (Schumaker, Barros, 1994). However, the species has also been recorded on mammals, such as cattle and rodents of the families Hidrochaeridae: Hydrochaeris hydrochaeris from the French Guyana (Floch, Fauran, 1959), and Echimyidae: Proechimys semispinosus from Venezuela (Jones et al., 1972), and Peromyscus gossypinus from Florida, USA (Durden et al., 1993). According to Dunn (1923), approximately $60 \%$ of the snake population, $72 \%$ of the toads, and $84 \%$ of the lizards and iguanas have been found infested by A. dissimile in Panama.

Regarding the life cycle under laboratory conditions, records include those of Dunn (1918) on Boa imperator, Oxybelis fulgidus, and Epicrates cenchria snakes, Brodkin (1918) and Schumaker and Barros (1994) on Bufo marinus toads, Brumpt (1934) on unidentified toads and iguanas and Manzanilla and Aponte (1999) on Iguana iguana. Larvae obtained from one engorged female of $A$. dissimile, collected on an Elaphe sp. snake from Central America, were also used as a vector for Cowdria ruminantium (Rickettsiales) in experimental studies with ruminants and reptiles (Jongejan, 1992). Although this tick is considered of little economic importance, severe lesions have been reported in heavily infested hosts (Fairchild et al., 1966).

The purpose of this study was to provide additional information on the host relations of $A$. dissimile and the lizard Tropidurus torquatus Wied, 1820 and the domestic rabbit Oryctolagus cuniculus Linnaeus, 1758, under experimental conditions.

This experiment was carried out at the W. O. Neitz Experimental Station, Department of Animal Parasitology of the Universidade Federal Rural do Rio de Janeiro, Brazil.

Suporte financeiro: CNPq, CAPES e FAPESP (Programa Biota-Fapesp No 99/05446-8 DMBB)

Recebido para publicação em 13 de dezembro de 2002

Recebido para publicação, após modificações, em 18 de junho de 2003

E-mail: lhtf@ufrrj.br

The Protocol on Ethical Principles in Animal Research adopted by the Brazilian College of Animal Experimentation (COBEA) was followed in this paper. 
The tick colony started out with two females of A. dissimile, naturally engorged on an Iguana iguana, kept in the zoo of the Universidade Federal de Mato Grosso. After weighing, both females were kept in an incubator at $27 \pm 1^{\circ} \mathrm{C}, \mathrm{RH}$ $\geq 80 \%$ and scotophase. The ticks were identified according to Guimarães et al. (2001). Two T. torquatus lizards from a highland region near Seropédica County (Serra das Araras), State of Rio de Janeiro and two O. cuniculus rabbits donated by the Instituto de Zootecnia, Universidade Federal Rural do Rio Janeiro were used as hosts.

Approximately 590 larvae that emerged from the eggs of the one female were released over the lizards' dorsum midline, whereas approximately 140 larvae that emerged from the eggs of the second female were used to infest the rabbits' ears. All larvae were 15 to 25 days old by the time of infestation. The lizard was kept in a $55 \times 70 \times 40 \mathrm{~cm}$ plastic cage with vaseline on the edges to prevent the ticks' escape. This procedure was not necessary for the rabbits since the ticks were enclosed in cloth hoods, according to the procedure described by Neitz et al. (1971).

Fifteen to 25 days after the molting of the engorged larvae, which occurred under the same controlled conditions, 24 and 19 nymphs were used for artificial infestations on the same lizard and another rabbit, respectively, following the same methodology adopted for larval infestation.

The parasitic phase of both larvae and nymphs was observed daily. The engorged and naturally detached ticks were placed in plastic vials with cotton stoppers, under the same, previously described, controlled conditions and observed daily until molting to nymph and adult, respectively.

The results for the experimental infestations with A. dissimile larvae and nymphs, on both hosts, are shown on Table 1.

Table 1. Parameters of infestation with larvae and nymphs of Amblyomma dissimile on lizards and rabbits under laboratory conditions

\begin{tabular}{|c|c|c|c|c|}
\hline \multirow{2}{*}{ Parameter } & \multicolumn{4}{|c|}{ Tick stage } \\
\hline & \multicolumn{2}{|c|}{ Larvae } & \multicolumn{2}{|c|}{ Nymphs } \\
\hline Host & T.torquatus & O.cuniculus & T.torquatus & O.cuniculus \\
\hline $\mathrm{N}^{\mathrm{o}}$ of exposed ticks & 590 & 140 & $24+11$ & $19^{1}$ \\
\hline $\mathrm{N}^{\mathrm{o}}$ of engorged ticks $(\%)$ & $36(6.1)$ & $19(13.6)$ & $8(22.9)$ & 0 \\
\hline Feeding period (days) & $17-30$ & $5-7$ & $19-35$ & 0 \\
\hline Average molting period (days) ${ }^{2}$ & 12 & 7 & 15 & 0 \\
\hline $\mathrm{N}^{\mathrm{o}}$ of ticks that molted $(\%)^{2}$ & $30(83.3)$ & $19(100)$ & $8(100)$ & 0 \\
\hline
\end{tabular}
scotophase).

On the T. torquatus, fixation and the beginning of the engorging process of several larvae began one day after infestation. Engorging larvae were observed on the following regions of the host's body: right side of dorsum, left side at the base of the tail, around the femur - tibia - fibula joint, cervical region of black ring, left lateral abdomen and right armpit depression.

Out of the 730 larvae, resulting from the infestations on lizard (590) and rabbit (140), only $43(5.9 \%)$ nymphs were able to resume the life cycle, 24 and 19 nymphs were released on the lizard and domestic rabbit, respectively. Nymphs released from the rabbit did not attach it and eight had already died on the seventh day after infestation. The 11 remaining nymphs were, then, transferred to the lizard. Out of the 35 nymphs used to infest the lizard, only eight $(22.9 \%)$ engorged and were recovered between the $19^{\text {th }}$ and $35^{\text {th }}$ day. All nymphs molted, resulting in six males and two females. One female presented a morphological anomaly on the scutum and died soon after molting.

For the infestation of the adult stages of $A$. dissimile, another lizard of the same species and from the same locality, was used. A replacement of the host was necessary due to contamination of the first lizard with fungi. The lizard was treated and released in its natural environment, where total recovery was observed. 
Approximately 15 days after molting, adult ticks were placed on the host. However, none attached it, and the single female died within 48 hours, preventing the observation of the rest of the life cycle.

The percentage of engorged larvae (Table 1) recovered on the lizard, in the present study, was very low when compared to that reported for snakes (Dunn, 1918). Dunn obtained 49 (24.5\%) recovered larvae, from a total of 200 used in the infestation. The low percentage obtained in the present study might be due to the heavy infestation, to which the host was subjected (crowding effect), although there is no determined pattern for the number of larvae used on previous infestations. The age of the larvae might be another factor that contributed to low success. In previous studies (Dunn, 1918; Brodkin, 1918) approximately 30 day old larvae were used.

The larval parasitic period as well as that of the molting period on lizards, observed in the present study (Table 1), were similar to those reported for snakes, under $26^{\circ} \mathrm{C}$ average temperatures (Dunn, 1918). However, these values were different from those reported for $B$. marinus (Schumaker, Barros, 1994). These authors reported a higher range (12 to 47 days) for the parasitic stage and a longer molting period (13 to 35 days). Manzanilla and Aponte (1999) reported lower values for the parasitic stage (10 to 14 days), however, with longer molting periods (12 to 20 days). The feeding period range for nymphs was higher than that obtained for $B$. marinus (Schumaker, Barros, 1994), and differs from other data available on the literature (Dunn, 1918; Brodkin, 1918). The nymphal parasitic period, reported by Manzanilla and Aponte (1999), was almost twice as short (10 to 15 days) as the one obtained in the present study. On the other hand, the nymphs molting period, at room temperature (Schumaker, Barros, 1994), was twice as longer as the one observed in the present study, which in turn, was similar to that reported for nymphs maintained under controlled temperatures (Dunn, 1918; Brodkin, 1918). These differences might be due to the hosts used in the experiments.

Concerning the proportion of males and females, Schumaker and Barros (1994) obtained 16 males and two females. This proportion was similar to that obtained in this study, for $T$. torquatus. Nevertheless, Manzanilla and Aponte (1999) obtained an inverse proportion of only one male and seven females. The same pattern was verified by Brodkin (1918), who obtained five males and 11 females, using B. marinus as host.

Although the rabbits used in this report were prevented from grooming, data on table 1 suggest that larvae of $A$. dissimile might be able to infest these hosts as already reported by Jongejan (1992) for goats. This study represents the first report on the parasitism by larvae and nymphs of $A$. dissimile on $T$. torquatus lizards and larvae on rabbits.

Keywords: Amblyomma dissimile, experimental infestation, larva, nymph, lizard, rabbit

\section{RESUMO}

Larvas provenientes de duas fêmeas de Amblyomma dissimile Koch, 1844 (Acari: Ixodidae), naturalmente ingurgitadas em uma iguana (Iguana iguana) e provenientes do Estado do Mato Grosso, foram utilizadas na infestação experimental de lagartos da espécie Tropidurus torquatus e coelhos domésticos. As larvas alimentadas em ambos os hospedeiros realizaram ecdise para ninfas. As ninfas apenas ingurgitaram no lagarto e mudaram para machos e fêmeas. Este é o primeiro registro do parasitismo de larvas e ninfas de A. dissimile em $\mathrm{T}$. torquatus e de larvas em coelhos.

Palavras-chave: Amblyomma dissimile, infestação experimental, larva, ninfa, lagarto, coelho 


\section{REFERENCES}

BRODKIN, G.E. The biology of Amblyomma dissimile Koch, with an account of its power of reproducing parthenogenetically. Parasitology, v.11, p.10-17, 1918.

BRUMPT, E. L'Ixodiné Amblyomma dissimile du Venezuela ne presente pás de parthénogenèse facultative. Ann. Parasitol., v.12, p.116-120, 1934.

DUNN, L.H. Studies on the iguana tick Amblyomma dissimile, in Panama. J. Parasitol., v.5, p.1-10, 1918.

DUNN, L.H. The ticks of Panama, their hosts and the diseases they transmit. Am. J. Trop. Med., v.3, p.91-104, 1923.

DURDEN, L.A.; KLOMPEN, J.S.; KEIRANS, J.E. Parasitic arthropods of sympatric opossums, cotton rats, and cotton mice from Meritt Island $J$. Parasitol., v.79, p.283-286, 1993.

FAIRCHILD, G.B.; KOHLS, G.M.; TIPTON, V.J. The ticks of Panama (Acarina: Ixodoidea). In: WENZEL, R.L.; TIPTON, V.J. (Eds.). Ectoparasites of Panama. Chicago: Field Museum of Natural History, 1966. p.167-219

FLOCH, H.; FAURAN, P. Les Ixodidae du genre Amblyomma en Guyane et aux Antilles Françaises. Acarologia, v.1, p.216-227, 1959.
GUIMARÃES, J.H.; TUCCI, E.C.; BARROSBATTESTI, D.M. Ectoparasitos de importância veterinária. São Paulo: Plêiade/Fapesp, 2001. $218 \mathrm{p}$.

JONES, E.K.; CLIFFORD, C.M.; KEIRANS, J.E. et al. The ticks of Venezuela (Acarina: Ixodoidea) with a key to the species of Amblyomma in the western hemisphere. Brigham Young Univ. Sci. Bull Biol. Ser., v.17, p.1-40, 1972.

JONGEJAN, F. Experimental transmission of Cowdria ruminantium (Rickettsiales) by the American reptile tick Amblyomma dissimile Koch, 1844. Exp. Appl. Acarol., v.15, p.117-121, 1992.

MANZANILLA, J.; APONTE, O. Biologia de la garrapata Amblyomma dissimile (Acari: Ixodidae), ectoparasito de Iguana iguana (Reptiles: Iguanidae). Acta Biol. Venez., v.19, p.59-71, 1999.

NEITZ, W.O.; BOUGHTON, F.; WALTERS, H.S. Laboratory investigations on the karoo paralysis tick (Ixodes rubicundus Neumann, 1904). Onderstpoort J. Vet. Res., v.38, p. 215224, 1971.

SCHUMAKER, T.T.S.; BARROS, D.M. Notes on the biology of Amblyomma disimile Koch, 1844 (Acari: Ixodida) on Bufo marinus (Linnaeus, 1758) from Brazil. Mem. Inst. Oswaldo Cruz, v.89, p.29-31, 1994. 